DOI: https://doi.org/10.30525/978-9934-26-020-9-7

Vladimir Shedyakov

Dr. Sc. (Sociology), Ph.D. (Economics), free-lance

\title{
THE MASTERY OF SOCIAL PEDAGOGY IS AN INTEGRAL CONDITION OF ORGANIC ECONOMIC DEVELOPMENT
}

\section{Summary}

The purpose of the work is an intermediate summarization of study of the economic significance of experience and historical transformations of social pedagogy from the perspective of the tasks of providing organic ways for the people to increase the level of public safety and development as a condition for the effectiveness of anti-crisis regulation. The applied methods are based on the unity of historical and logical elements, analysis and synthesis. When preparing to participate in the confrontation of cultural and civilizational worlds covering different spheres of life, it is extremely important to be able to apply the best of the past to solve new problems. In particular, both effective anti-crisis regulation and successful protection of national interests and their identity presuppose a careful attitude to the basic value-semantic complexes in the spiritual and moral forms of communication and development. This, in turn, focuses on a special consideration of the period of intensive personality formation, maturation and civil development of a person in providing anti-crisis regulation. So, social pedagogy should not only focus on the changing structure of the economy, but it also should reflect the development of economic perception of the possibilities of controllability, self-control and uncontrollability with increasing uncertainty of the environment. This lays the foundation for a fluid balance of strategy, tactics and operations in management compositions, increasing the effectiveness of anti-crisis measures.

\section{Введение}

Человечество вплотную подошло к кардинальной развилке на своём пути. В этой ситуации эффективны не изолированные антикризисные меры, а комплексный организационно-управленческий подход, проистекающий как из основных тенденций преобразований, так и из особенностей переходного периода [1-5]. Разумеется, неожиданностями реальность богаче фантастики. Судьба дальнейших орбит во многом зависит от качества проводимых трансформаций. Вместе с тем, стремительно возросшая роль «экономики знаний» требует адекватной научно-образовательно-производственной опоры. Вектор основного стержня общественного движения задаётся задачами обеспечения 
равенства, свободы и справедливости. «Родимые пятна» прошлого и мгновения будущего перемежаются и взаиморезонируют.

Органичному движению вперёд свойственно преодоление однобокости подходов в пользу стереоскопичности, объёмности понимания явлений и процессов с голографичностью миропонимания. Между тем, уровень осознания и понимания социально-экономических процессов крайне неадекватен стоящим Вызовам. Обрушившееся цунами из разнообразных гуру, самоназванных мастеров, психоделических практик и тренингов естественно. С одной стороны, оно отражает существо «потерянного поколения» без идеологических и нравственных ориентиров. С другой, - активно прививается потребительское желание «ухватить по-быстрому» (не только материально, но и духовно), без особых усилий, отчуждённо уединившись в своём кружке, и уж разумеется без действительного понимания социальной ответственности. А на самом глубоком уровне время требует перемен не только мироустройства, но и массового воспитания и образования. Достижение морально-нравственной, культурной, политико-идеологической зрелости критической массой людей - условие успешного перехода и использования «межевого времени». Тактические же организационно-управленческие формы зависят от конкретной ситуации. Соответственно, крайне важны: профессионализм и нравственность элит, отход от шаблонов «голого» администрирования, овладение новейшими технологиями, персональная ответственность за организационно-управленческие ошибки. Характер возникающей при переходе к новой общественной парадигме в единстве внутреннего устройства и мирового порядка сам по себе отнюдь не обрекает на хаос и бессмысленность, но требует концептуальнометодологического знания и восприятия. Масса накопленных фактов сама по себе не гарантирует качество управления.

Обеспечение исторической субъектности народа и качества участия в создании общества знаний требует как комплексного преобразования общественной среды, так и формирования точек концентрации позитивных изменений (прежде всего, научно-образовательнопроизводственных кластеров). Соответствующие этим закономерностям некоторые идеи Б. Бим-Бада, А. Бине, П. Блонского, Ф. Вернона, И. Гербарта, Ж. Жакото, Я. Коменского, Г. Косицкого, П. Кропоткина, А. Макаренко, И. Мечникова, Р. Оуэна, И. Песталоцци, Ж.-Ж. Руссо, Г. Сковороды, В. Сухомлинского, К. Тимирязева, Н. Трубникова, К. Ушинского, П. Флоренского, Ф. Фрёбеля, В. Шаталова, С. Шацкого, Д. Эльконина, П. Эрджиева, а также школами игротехники, мастерской управления «Сенеж», в частности, разработками В. Андреева, T. Артемьевой, А. Асмоловой, М. Афониной, В. Бабкиной, Л. Балашовой, Л. Барановой, Е. Белозерцева, Д. Богоявленской, Л. Божович, А. Вейхера, П. Гальперина, А. Горца, Б. Дегтярёва, 
В. Ельмеева, А. Запорожца, Л. Земцовой, Е. Ильина, А. Каспаржака, Г. Кравцова, А. Кузьминского, О. Кусакиной, В. Лекторского, И. Лернер, Г. Лозанова, Е. Лопатина, А. Лурии, В. Маху, Дж. Маккензи, В. Мухиной, Ю. Озаровского, Г. Палаткиной, М. Рокара, И. Семёнова, T. Симона, А. Смолкина, Е. Солдаткиной, О. Трубниковой, Г. Урунтаевой, Л. Фридмана, И. Фрумина, И. Шалаева, А. Щербакова, Л. Ясюковой реактуализируются характером постсовременности, многие черты общественной психологии и идеологии в воспроизводстве ценностной ситуации отражены, в частности, П. Абеляром, С. Аверинцевым, Б. Ананьевым, Л. Архангельским, С. Батениным, М. Бахтиным, Н. Бердяевым, В. Букреевым, Л. Выготским, Г. Гиргиновым, Е. Головахой, Ю. Давыдовым, Б. Додоновым, О. Дробницким, А. Захаровой, Э. Ильенковым, Х. Йоасом, М. Каганом, П. Копниным, Р. Косолаповым, А. Леонтьевым, А. Лосевым, В. Малинковичем, Э. Маркаряном, В. Мерлиным, П. делла Мирандолой, Л. Нагорной, Н. Паниной, А. Петровским, Ж. Пиаже, Я. Пономарёвым, Ю. Плетниковым, В. Сагатовским, Г. Селье, А. Спиркиным, Е. Спицыным, В. Толстых, В. Тугариновым, А. Уледовым, В. Фофановым, И. Фроловым, У. Цвингли, Р. Чалдини, Ю. Шайгородским, И. Эригеной и др. Крайне важны обобщения, сделанные при исследовании творчества отдельных личностей и коллективов Д. Валовым, Г. Волковым, Д. Граниным, В. Дудинцевым, И. Ефремовым, Н. Комиссаренко, Т. Куном, С. Мельник, В. Пошатаевым, А. и Б. Стругацкими, В. Тендряковым, показавшими, в частности, что раздвижение горизонтов познания - это и дорога к себе.

Основная задача текста - осмысление необходимости и возможностей социальной педагогики как фактора и, в частности, подготовки и реализации органичного экономического развития и, в частности, эффективного антикризисного курса.

\section{Раздел 1. Социальная педагогика в структуре общественных безопасности и развития}

Антикризисное регулирование встраивается в переориентацию общества и реструктуризацию экономики. При этом и сам постсовременный продуктивный капитал зримо формируется вокруг творческих возможностей и интеллектуального потенциала человека, их организации и использования. Обеспечение же экономического суверенитета требует актуализации ресурсно-методологических баз эндогенного развития и акцентирования новейших техникотехнологических укладов глубокой переработки при повышении веса интеллектоёмкого творчества [6-8].

В свою очередь, расцвет науки, культуры, искусства, технологий требует свободы мысли в приемлемых для населения формах. Соответственно, политико-экономические ресурсы власти должны не 
подавлять или тормозить образовательные структуры, а партнёрски участвовать в социальной мере педагогики. При этом, по словам И.И. Мечникова, «человек должен посвятить большую часть своего существования на полное развитие собственной личности и что только достигнув второй половины жизни, умудрённый опытом и удовлетворённый личной жизнью, должен он посвятить свою деятельность на благо людей» [9, с. 251]. Если первая половина жизни нормативно генерализуется необходимостью «доказать себя миру» личными достижениями профессионализма и подвержена эгоистичным мотивам, то вторая наполнена широким диапазоном организаторских возможностей и альтруистическими смыслами работы для общей пользы всего общества (отсюда - повсеместные практики советов старейшин).

При этом значение социальной педагогики в осуществлении антикризисного регулирования многообразно. Социальная педагогика элемент системы воспроизводства социокультурного капитала, отражающая представления общества о дереве целей и ресурснометодологических базах социальной инженерии [10-12]. Социальная педагогика сохраняет, приумножает и формообразует восприятие идеального и реального, интегрирует в сакральные коммуникации, предоставляя средства сведения фундаментальных и актуальных пластов действительности. Так, в зависимости от состояния общественной среды формы проявления моральных дилемм могут иметь как интегрирующий, так и фрустрирующий характер. Что, в свою очередь, повышает значимость культивирования и общей социальной ткани культурноцивилизационного мира, и кластеров выращивания нового (см. постоянные возвращения Стругацких к тематике педагогического «парника» в цикле о педагогическом лицее Ташлинска). Собственно, ассоциирование индивидуального мастерства и кумулятивной синергетики среды и позволяет «сшивать» национальные особеннсти культурно-цивилизационных миров с разнообразными достижениями и наработками. Впрочем, поддержание традиционных нравственных начал, обеспечение их инновационными формами имеет не только культурообразующее значение, но и государственнообразующую роль. Так, повышение социальной ответственности и нравственной требовательности во всех сферах жизнедеятельности - необходимость и отражения условий общества знания, и наполнения практическим смыслом структур социального государства. Особенно велико скрепляющее звучание нравственных ориентиров, представлений о совести, справедливости, нормальности, долженствовании и т.д. для разделённых народов, когда государства по-разному трактуют свою миссию, а их элиты - мораль. Патологизация общества ведёт к ложной социальной стоимости, чуть ли не извращённо-иррациональной моде на эгоистичных социопатов, органичное развитие предполагает 
разветвлённую систему социальной защиты, в т.ч. базовых ценностносмысловых комплексов культурно-цивилизационных миров [13-15].

Состояние и динамика социальной педагогики значимо влияет на общественный иммунитет. В свою очередь, как уровень общественного иммунитета (прежде всего, состояние социальной среды), так и качество связи правящей и оппозиционной элиты с народом сказывается на соотношении возможности и предрешённости выбора, на его диапазоне, в т.ч. и на действенности антикризисных мер [16-18]. Например, поведение во время эпидемии проявило различия в прочности не только систем здравоохранения, но и социальной педагогики. Высочайший статус людей, создающих и передающих знание, в Советском Союзе (чего стоит одна годами шедшая на страницах «Учительской газеты» общественная дискуссия о том, не уронит ли престиж профессии сельский учитель, если заведёт подсобное хозяйство) сочетался с уважением к процессу приобретения образования как необходимости понимания и умений. Однако, стимулирование творческого подхода и критичности мышления (достаточно упомянуть регулярные сочиненияразмышления), развитие творческого подхода и самостоятельности поступков при огромном разнообразии педагогических стилей были значительно подорваны стремительной деградацией в 90-х гг. ХХ века. Активно навязывались стереотипы западного «общества потребления» и культ денег, падали материальное благосостояние и социальный престиж тружеников. Соответствие состояния и динамики общества требованиям времени, культивирование социальной среды, стимулирующей желательные перемены, требуют достижения нового баланса индивидуального и социального начал жизнедеятельности, что актуализирует как ресурсно-методологические базы социальной педагогики, так и возрождение кадровой системы. Лавинообразное распространение болезнетворных бактерий не только притормозило, «заморозило» решение стоявших социально-политических проблем, но и внесло коррективы в реализацию крупномасштабных перемен. Разумеется, пандемия не стала причиной глобальных трансформаций, но оказалась важным фактором и «лакмусовой бумагой» парадигмальных подвижек исторического уровня.

Плодотворная защита исторической памяти при понимании всемирноисторического процесса как непрерывного и постоянного требует учить население размышлять, действовать, творить: самостоятельно и в коллективе. Сейчас же роль социальной педагогики как фактора общественного развития взлетает, прежде всего, из-за особенностей нарождяющегося общественного устройства с отчётливой интеллектуально-духовной доминантой (что и отражено в ряде определений, например, при характеристике «общества знания»), а также недостаточности качеств правящего слоя. Причём если капиталистический вариант модерна строил общество по экономическим лекалам, 
то социалистический - по социальным. К тому же приоритетом становится создание условий для сознательной жизнедеятельности, разумной инициативы и гражданской активности каждого: укрепление иммунных возможностей культурно-цивилизационных миров требует своевременной модернизации не только информационных инфраструктур, но и системы воспитания критичного мышления у населения, a также воспитания привычки к осознанному участию народа в управлении общественной жизнью. Утверждение демократических принципов регулирования жизнеустройства также кардинально увеличивает значимость социальной педагогики: массовое развитие творчества (прежде всего, в труде и управлении) требует адекватных образованности и воспитания. Дистанционное обучение как вынужденная эрзац-коммуникация может на какое-то время подменить действительное общение, но способно лишь дополнять «живое» взаимодействие.

Смена общественных парадигм в данном случае выступает как закономерное восхождение к более цельному пониманию самого феномена образованности, в структуру которого теперь должны войти не только познавательный, деятельностный и творческий опыт, но и опыт собственно духовно-цельной самоорганизации человека, связанный с выполнением им смыслопоисковых, рефлексивных, самооценочных, жизненно-плановых и др. функций [19-22]. Для органичности развития общества необходимо воспитывать не потребителя, a созидателя, укоренёёного в пластах культуры и овладевшего социальным наследием духовно богатого человека.

Причём постглобальный межпарадигмальный скачок означает уже не просто переход политико-экономического лидерства от одного государства к другому, а смену типа структурирования и приоритетов. Собственно, конкурентная борьба идёт отнюдь не за более точное и своевременное овладение какой-либо одной моделью обеспечения безопасности и развития общества, а между кардинально разными подходами. В этом смысле переходный межпарадигмальный период это и «возвращение к себе», и проведение модернизации на своей собственной основе. Полицентризм и ризомичность развития заведомо отрицают и единственность «точки сбора» будущего, и общность модели развития. Формируется ряд взаимодействующих центров, каждый из которых культивирует удобные для себя варианты структурирования общественной жизни и воспитания. Да и заинтересованы во взаимодействии и взаимодополнении, как правило, отличные друг от друга, а отнюдь не единообразные явления. Вместе с тем по-прежнему любые попытки «введения единообразия» мешают творческому поиску, препятствуют развитию. Развитие ойкумены отходит от схем «центр(ы) - полупериферия - периферия» к гибкому и изменчивому взаимодействию разноуровневых акторов, где ведущие 
роли играют культурно-цивилизационные миры, имеющие в качестве своих духовно-нравственных стержней базовые ценностно-смысловые комплексы. Они становятся мультипликаторами силы народов и создают миссию и мораль государства, наращивая социокультурный потенциал общества. Опора на них позволяет не только разбудить и сконцентрировать, но и сэкономить социальную энергию. Они же в конечном итоге предопределяют, какое состояние общественного пространства рассматривается как пригодное для жизни и развития, т.е. формируют консенсус. Именно они, закрепляясь матрицами ментальных кодов народов, фиксируют расхождения в обычаях, воспитании, престиже, моде, влияют на вектор трансформаций эмоционального интеллекта общества, предопределяют общественные предпочтения, поведение и исторический выбор.

Периодические трансформации парадигмального качества неизбежность развития как, в частности, «повивальная бабка истории». Но сам период форсированных изменений, разумеется, - это не время приращения на установившейся основе, соответственно, вовсе не эпоха процветания, а эра кризиса и выхода на поверхность накопленных противоречий, поляризации общества и обострения борьбы [23-26]. Сущность взаимоподдержки традиций и инноваций общественного развития - в политико-экономическом устройстве порядка жизни, который, чтобы быть созидательным, должен восприниматься народом как справедливый, должный. Для этого, в свою очередь, не должно существовать привилегий для власть имущих и агрессивных меньшинств, размежевание не должно прикрываться лживыми лозунгами и т.д. Требуется тщательное формирование жизненной позиции безотносительно индивидуальных особенностей характера и стиля поведения, хоть реализуется она именно через личностное разнообразие. Ответственная и разумная реализация свободы совести и права выбора требует тщательной подготовки, становящейся делом общегосударственной важности. Перед обществом именно как комплексная социальная задача встаёт необходимость качественного изменения личности, в частности - средствами воспитания и образования. Отсюда - колоссальная политико-экономическая нагрузка на педагогический цикл на переходном этапе ойкумены.

Пороговое состояние ойкумены делает неизбежным кардинальное совершенствование человека, в частности - системное образование личности в едином процессе дошкольного, школьного, послешкольного образования, регулярной переподготовки и постоянного самообразования. Усложнение социума требует овладения методами общественно полезного использования (а подчас и ненасильственной нейтрализации) самой разнообразной индивидуальной энергии. Вместе с тем, часто принятие решений осуществляется под несознаваемым воздействием иррациональных факторов (разум в дальнейшем лишь 
легитимирует, разъясняет и упорядочивает уже принятое, ищет пути к реализации); закономерность пробивается посредством случайностей, тех или иных отклонений в конкретном случае. Соответственно, для каждой ситуации крайне существенна позиция участников событий: их опыта, личной, семейной и социальной памяти, интуиции традиций, волевых качеств, рейтинга влияющих факторов. Новое состояние общества, как внутреннего, так и внешнего структурирования целостности социальных связей увеличивает заинтересованность в формировании адекватных человеческих качеств, инновационном состоянии меры индивидуализации - социализации / аккультурации. Одновременно нарастают как единство в восприятие социальных стандартов жизни и деятельности, так и культурно-цивилизациооные различия в ценностно-смысловой интерпретации происходящего. При этом в личной и кланово-групповой унии сплетаются ветви власти: идеологической, экономической, политической и т.п., выхолащивая принципы народовластия и гуманизма, извращая социальное полотно.

Вместе с тем, произошедшее в планетарном масштабе радикальное обобществление воспроизводства требует не только адекватной диффузии содержания отношений (и прежде всего, демократизации и гуманизации системообразующих отношений труда, собственности и управления), но и восстановления меры планирования экономических процессов [27-30]. Соответственно, использование аграрного комплекса, туристических возможностей или же транзитного положения (будучи, бесспорно, важным) не являются основой ни долговременного гармоничного подъёма, ни даже экономического суверенитета. Требуется радикальная активизация научно-интеллектуального потенциала, стало быть, действительная приоритетность образовательно-научно-производственного комплекса, преодоление тенденций к деиндустриализации и контрмодерну. Кроме того, на разных фазах трансформаций решение задач общественного согласия может предполагать разные акценты в социальной педагогике. Дополнительно роль многовекторного разнообразия и разумной инициативы подчёркивается усилением черт ризомы в социальноэкономическом развитии. Меняется качество социально-экономического развития, где место гонки за расширением рынков и, соответственно, подталкивания стяжательства и потребительства начинают занимать духовно-нравственные горизонты и интеллектуальное творчество. Более того, как раз бесплодные попытки помешать ходу истории, сохранив наличные отношения и иерархии (пусть и с применением всё новых подходов), зримо выступают весомым фактором не только духовнонравственной эрозии, но и военно-политических противостояний. За эффективными анализом и объяснением предоставляет возможности не только прогнозирования, но и конструктивного влияния на процессы, а также поддержания пропорциональности и оптимальности балансов. 
Соответственно, планирование - важнейшая часть управления процессами. Одновременно накапливаются и риски от промедления в проведении назревших реформ в организации и регулировании экономической жизни ойкумены.

\section{Раздел 2. Научно-образовательно-производственные кластеры в создании новых общественных условий}

Индивидуальное мастерство педагога приобретает общественное звучание, закрепляясь как атрибутивное качество социальной педагогики. Новое общество и новый человек, востребуемые складывающимися условиями, с одной стороны, производны от обстоятельств, с другой, - их активные творцы. Обе стороны объектсубъектного отношения испытываются на излом особенностями как постглобальных динамик, так и периода форсированных перемен. Социальная педагогика базируется на индивидуальных особенностях участников образовательного процесса, закладываясь, в частности, сотворчеством, со-развитием взаимодействующих. Естественно, что конвейеризация общественно и личностно важных инноваций вынуждает к кардинальному изменению стиля жизни и места в обществе прежде всего именно слой педагогов и учёных. Одновременно, обеспечение исторической субъектности народа и становление гражданского общества при переходе к обществу знания тесно связаны с совершенствованием организационно-управленческих (в частности, психолого-педагогических) отношений. Достижение соответствия социокультурных полей возможностям и рискам «умного общества» требует коррекции как отношений на осях «общество - государство бизнес», так и «человек - культурно-цивилизационный мир». При этом ныне преподаватель из «озвучивателя банальных истин» превращается в консультанта и мотиватора, а прежде всего - в воспитателя. И совсем не только для студентов своего вуза, а в разрезе соответствующего научнообразовательно-производственного комплекса. Впрочем, если в лидирующих странах основная часть дохода преподавателей смещается в направлении оплаты практического консультирования и исследовательских грантов (стимулируя проникновение знаний «вглубь»), то на полупериферии в заурядных вузах зачастую для поддержания благосостояния вынуждены множить нагрузку и разнообразие читаемых курсов (подталкивая к освоению «вширь»).

Гармонизация индивидуального и социального, баланс составляющих открытости и закрытости, возможностей пострыночного механизма и публично-приватного взаимодействия предусматривает при этом формы сочетания энергии частной инициативы и предпринимательства с гибким государственным регулированием. И, как известно, отечественными педагогическими школами накоплен богатый опыт воспитывающих (в частности, проектных) организации и мотивирования 
сотворчества и взаимопомощи как органической солидарности учащихся, форм обретения себя, развития дарований каждого, познания и преображения мира в процессе этого. Организационно-управленческие трансформации ещё раз напоминают о наличии трёх главных измерений: обеспечения индивидуальных и прав человека, подъёма социальноэкономического благосостояния и политического сознания. Эти направления взаимосвязаны, при этом, например, высокий уровень культуры вложений в образование и профессиональную подготовку, науку, здравоохранение и социальное обеспечении работников неотъемлемая черта превращения человеческого потенциала в человеческий фактор, а также его расширенного воспроизводства. Органичность развития социальной педагогики закладывается, в первую очередь, балансом традиционности и инноватики, фундаментального и актуального, следовательно, - культивированием новых, адекватных задачам и средствам времени, форм базовых ценностно-смысловых комплексов культурно-цивилизационных миров, сочетанием ментальных матриц и социального опыта. Историческая память, в частности, сохранила знание того, как именно в процессах дошкольного, школьного и послешкольного воспитания и образования СССР крайне эффективно развивались разнообразные проблемные и ролевые игры, позднее перераставшие в игры деловые (а в воинском искусстве - в военно-штабные). Тем самым создавался и мотивировался творческий поход к решению жизненных задач, прививались взаимопомощь, сострадание, чуткость, взаимопроверка и подстраховка, тщательность в деталях при выдерживании общей стратегии, готовность сделать побольше ради общего результата и т.п. Внедрялись элементы научной организации деятельности; в частности, этому служили дневники наблюдений за природой, чтения, культура разносрочного планирования. Высоко ценился личный пример педагогов (не «делай так», а «делай так, как я»), шефов, старшеклассников. Культура образования базировалась как на поддержании и культивировании природной детской любознательности, так и на раннем выявлении личностных склонностей. Ещё ребёнком человека «учили учиться» самому и помогать другим, взаимно усиливая навыки и дарования каждого. Готовность к самопожертвованию и риску во имя общих свершений поддерживалась не только социальной и семейной памятью, но и характером общественных отношений. Постоянные сверхдостижения по всем важным азимутам (достаточно упомянуть о приоритетности в выводе на орбиту первого искусственного спутника, животных, космонавта, женщины, многонационального экипажа, выхода в открытый космос, создании реактивного пассажирского лайнера и т.д.), что формировало идеологию и психологию. Общая атмосфера нацеливала на сочетание стремления вперёд с умением работы в коллективе при максимальных нагрузках и с полной самооотдачей, поощряла поиск и 
разумную инициативу при высокой самодисциплине. Достаточно сравнить советскую фантастику открытия новых миров и контакта с ещё неизведанным с воспеванием атавизмов лже-средневековья в сюжетах фэнтази. Вектор различий столь очевиден, что просто просился в канву социальной педагогики (что и получило отражение в цикле произведения Н. Некрасова).

Двойная нагрузка образования - не только когнитивно-познавательная, но и формирующая личность и общество, обеспечивающая качество социализации / аккультурации - закрепляется балансом стремления к овладению и методологической грамотностью, и профессиональным мастерством. Дошкольное, школьное и послешкольное образование было нацелено не только на воспитание понимания окружающего мира и самого себя, но и на формирование навыков практического бережного отношения к природе и человеку. Так, и в направлении профессионально-технического знания (ФЗУ-ПТУ-ГПТУ), и в средних общеобразовательных школах (за счёт уроков труда и самообслуживания, а в старших классах - в УПК, учебнопроизводственных комбинатах) стремились к освоению как массовых рабочих профессий, так и наиболее передовых специальностей. По окончанию каждого класса школы обязательны были отработки определённой длительности на посильной общественно полезной деятельности, в вузах - третий трудовой семестр (два месяца), часто на младших курсах сочетавшийся с поездкой учебных групп с преподавателями на «картошку» (помощь сельским труженикам в сборе урожая). Это дополнялось отчётливым звучанием темы созидания во всех сферах общественной жизни: выделением личных трудовых специализаций в октябрятских «звёздочках», жизни пионерских дружин, трудового сектора всех уровней комсомольской жизни, ССО и СХСО вузовских организаций, разнообразных формах самоорганизации активистов-тимуровцев, сборах металлолома и макулатуры, разнообразных формах внеучебной активности (в т.ч. при подготовке тематических «вечеров», индивидуальных и командных профильных состязаний. Как известно «звёздочки» формировались таким образом, чтобы в каждую из них входили дети с одарённостью и интересом к одному из пяти (по числу лучиков звезды) выделенных основных направлений развития, так что каждый и специализированно изучал чтото одно (например, оказание медицинской помощи), и помогал остальным в его освоении. Пытливая любознательность и кропотливая тщательность поощрялись, поддерживаясь огромным количеством развивающих радио- и телепередач. Вся жизнь была пронизана сочетанием экологии и развития (всё - многоразового использования, в дальнейшем - быстро разложимое и допускающее вторичное применение); например, не употребляли пластик, в ходу были «авоськи», регулярно проводились сборы макулатуры и металлолома, 
постоянно осуществлялся уход за флорой и фауной, не только за деревьями и кустами, но и животным миром - в «живых уголках» и естественной среде обитания. Любовь к миру сочеталась с бережным отношением к Родине и окружающим, с малых лет изучали как краеведение, так и примеры патриотизма. При этом ориентация на общественные потребности настоящего и будущего в росте творческого подхода и индивидуального мастерства в процессе образования личности (её формирования и созидания) закреплялись педагогикой сотрудничества. Педагогика сотрудничества пронизывала не только отношения «учитель-ученик», но и «учитель-учитель» и «ученикученик» (где удачно дополнялась психологическими законами дружеской состязательности). Она подкреплялась взаимопомощью и взаимопроверкой учениками (студентами) работ друг друга, заботливой поддержкой старшекурсниками (-классниками) младшекурсников (-классников). И тут максимальное доверие к человеку воспитывало в нём высочайшую ответственность, уважение к труду, образованию, экосистеме. Причём нахождение в огромном количестве коллективов на протяжение взросления (за счёт участия в разнообразных кружках по интересам, работы Дворцов пионеров, Домов творчества молодёжи, Дворцов культуры, Детских и юношеских библиотек с неисчислимыми сопутствующими группами, спортивных школ, разнообразных факультативов и т.п.) при многообразии разных внешкольных и вневузовских мероприятий, а также параллельной работы ученических систем идейно-воспитательной активности и образовательной дисциплины (сбор пионерских дружин - старостат; ученический актив комсомольская организация) каждый учился в коллективе одновременно руководить и исполнять, готовился к ответственному принятию и реализации решений, критичному мышлению и практической деятельности, сочетать «уважение к вечному» и поиски «своей колеи».

Так, формирование образовательного пространства в значительной мере задаётся ведущим - Мастером. Личность учителя в соответствии с собственными способностями, убеждением, опытом, задачами влияет на личности учеников. Миссия учителя - не просто быть посредником в передаче накопленных человечеством знаний, но и уметь вдохновлять на жизненный путь поиска, работу самосовершенствования, в т.ч. за счёт приобретения новых знаний, умений, навыков. Для этого требуется вовсе не бессистемный ворох натасканной отовсюду информации, а глубинное понимание процессов, в частности, ради конструктивного действия, при обеспечении единства эмоциональных и интеллектуальных факторов освоения бытия. Совокупность находящихся во взаимном общении неповторимых индивидуальностей создают отличительные черты образовательного процесса. Причём коммуникация устанавливается не посредством красок (как у художника) или же музыкальных инструментов, а впрямую, 
непосредственно. И влияет не только уровень владения своим предметом или общеобразовательная эрудиция, но и отношение к миру: убеждённость, искренность, нравственность и т.д. Мастер участвует в формировании и специалиста, и личности; от него требуется чуткость, деликатность, понимание красоты. При этом Мастер должен быть готов быть на виду (у классной доски и за кафедрой) и в тени (за научной работой). Соответственно - обладать как творческими задатками, техническим мастерством, так и душой.

\section{Выводы}

На переломе развития значимость социальной педагогики и индивидуального мастерства педагогов неизмеримо возрастает. Другими словами, индивидуальное мастерство приобретает общественное звучание, закрепляясь как атрибутивное качество социальной педагогики. Когда мировая система империализма включила в себя существенную часть стран реального социализма, во многом был исчерпан потенциал распространения посткапиталистической модели организации общественной жизни, нуждающейся не только во внутренней, но и во внешней эксплуатации (в частности, за счёт монопольно неэквивалентного обмена). Тем самым смена общественной парадигмы стала драматически необходимой. Укрупнённо конкурируют два пути: кастовое или социализированное устройство общества, каждый из которых связан со своим представлением о нормативном, справедливым и желательным в образе жизни, направлениях индивидуального и общественного изменения, структуре производства, распределения, обмена и потребления. Весомыми факторами в складывании конечного вектора выступают трансформации государства и воспитания человека.

Характер возникающей при переходе к новой общественной парадигме в единстве внутреннего устройства и мирового порядка сам по себе отнюдь не обрекает на хаос и бессмысленность, но требует концептуально-методологического знания и адекватности восприятия. Вместе с тем, наука и образование бессильны вывести общество из тупика при окоченевшем строе. Образование должно препятствовать тенденциям деградации и вульгаризации человека и общественной жизни, для чего преодолеть поверхностность и выйти на уровень не просто качественных знаний, позволяющих выход на новый техникотехнологический уклад, но и понимания смыслов. Продуктивные организационно-управленческие (в частности, психолого-педагогические) инновации ориентированы на более полное раскрытие индивидуальной одарённости человека и связаны с гуманизацией механизмов реализации публичных и приватных интересов в формах соборности и партнёрства вокруг базовых общественных ценностно-смысловых комплексов. Отсюда - укрепление основания развития общества, достойного участия 
в мировом полилоге, в усилении глобальных трендов в стратегической перспективе, в т.ч. в международной жизни. На повестке дня безотлагательное создание кадровой системы отбора и продвижения способных к компетентной квалифицированной защите национальных интересов и действительного суверенитета в меняющихся условиях.

Довузовское и вузовское образование должно готовить к будущему, сознательной активности в нём. И в соответствии с меняющимися условиями при высокой насыщенности информационного пространства всевозможными текстами необходимо, прежде всего, мотивировать, научить отбирать и добывать знания, понимать и применять их. При этом для верного понимания информации и выработки решений растёт ценность личного примера накала духовной (в частности, научноинтеллектуальной) жизни, a, значит, преподаватель должен быть исследователем. Потому на смену модели педагогараспространителя/передатчика готового знания пришёл педагог, ориентированный на творческий поиск и открытия. Одновременно, поскольку утрата смысла означает утрату подлинной жизни, подмену её той или иной фикцией, социализация и аккультурация - естественные элементы формирования личности, в т.ч. средствами образования.

Качественные общедоступные образование и медицина - не только условие нравственного и телесного здоровья народа (значит, высоких иммунных свойств культурно-цивилизационного мира), но и фактор оптимизации орбиты развития. Разумеется, усилия общества в переходный к новой общественной парадигме период сосредотачиваются как на создании научно-образовательно-производственных кластеров, так и на культивировании стимулирующей позитивные изменения общественной среды. Соответственно, использование аграрного комплекса, туристических возможностей или же транзитного положения (будучи, бесспорно, важным) не являются основой ни долговременного гармоничного подъёма, ни даже экономического суверенитета. Требуется радикальная активизация научно-интеллектуального потенциала, стало быть, действительная приоритетность образовательно-научнопроизводственного комплекса, преодоление тенденций к деиндустриализации и контрмодерну. Судьба народа и качество антикризисных мер определяется качеством образования, масштабом формируемой обществом, семьёй и педагогами личности.

\section{Список использованных источников:}

1. Galbraith J.K. Economics \& the Public Purpose. Boston : Meridian, 1988. 321 p.

2. Медведев В.А. Устойчивое развитие общества: модели, стратегия. Москва : Академия, 2010. $312 \mathrm{c}$.

3. Лукинов И.И. Эволюция экономических систем. Москва : Экономика, 2002. 568 с.

4. Шедяков В.Е. Антикризисные меры в контексте межпарадигмального перехода. Anti-Crisis Management: State, Region, Enterprise: Proceed. of III Intern. Scient. Conf. Le Mans, November 22, 2019. P. 10-13. 
5. Шедяков В.Е. Трансформации при становлении «умного общества»: циклы, управляемость, субъектность. From the Baltic to the Black Sea Region: the national models of economic systems: Proceed. of Intern. Scient.-Pract. Conf. Riga, March 25, 2016. P. 14-17.

6. Шедяков В.Е. Экономика управляемая, самоуправляемая и неуправляемая. Integrated business structures: models, processes, technologies: Proceed. of Intern. Scient. Conf. Chisinau, November 25, 2016. P. 5-7.

7. Шедяков В.Е. Активизация научно-интеллектуального потенциала как ресурс стратегического управления. Стратегії економічного розвитку: держава, регіон, niдприємство / заг. ред. К. С. Шапошникова та ін. Херсон : Гельветика, 2015. Т. II. С. $148-172$.

8. Шедяков В.Е. Возможности и риски эпохи: научно-исследовательская рефлексия - рефлексивное управление - рефлексивная модернизация. Management of modern socio-economic systems / ed. by J. Žukovskis, K. Shaposhnykov. Kaunas: Baltija Publishing, 2017. Vol. 1. P. 201-218.

9. Мечников И. И. Этюды оптимизма. Москва : Наука, 1988. 328 с.

10. Шедяков В.Е. Культура принятия и реализации решений в гиперконкурентной среде. Development of Socio-Economic Systems in a Global Competitive Environment: Proceed. of II Intern. Scient. Conf. Le Mans, May 24, 2019. P. 149-150.

11. Шедяков В.Е. Социальная педагогика и экономическая власть. Modern educational space: the transformation of national models in terms of integration: Proceed. of II Intern. Scient. Conf. Leipzig, October 25, 2019. P. 157-159.

12. Шедяков В.Е. Осуществление парадигмальных трансформаций: сорезонирование стратегии, тактики и оперативного искусства в управленческих композициях. Development and modernization of social sciences: experience of Poland and prospects of Ukraine / Maria Curie-Sklodowska University. Lublin : Baltija Publishing, 2017. P. 282-307.

13. Бузгалин А.В., Колганов А.И. Пределы капитала: методология и онтология. Москва : Культурная революция, 2009. 680 с.

14. Castells M. The Power of Identity. The Information Age: Economy, Society and Culture. Vol. II. NY. : Wiley-Blackwell, 2010. 584 p.

15. Trout J., Rivkin S. Differentiate or Die: Survival in Our Era of Killer Competition. New York : Wiley. 272 p.

16. Шедяков В.Е. Организационно-управленческие подвижки как отражение глобальных трансформаций. Anti-Crisis Management: State, Region, Enterprise: Proceed. of II Intern. Scient. Conf. Le Mans, November 23, 2018. Part I. P. 9-11.

17. Шедяков В.Е. Вектор постсоветских трансформаций как фактор глобальных преобразований. Economy and Society: the Modern Foundation for Human Development: Proceed. of III Intern. Scient. Conf. Leipzig, April 26, 2019. P. 40-41.

18. Шедяков В.Е. Укрепление социокультурного основания - условие устойчивого политико-экономического развития. Modern Transformations in Economics and Management: Proceed. of IV Intern. Scient.-Pract. Conf.. Klaipeda, March 27, 2020. P. 85-88.

19. Сериков В.В. Парадигма современного образования: ориентация на личность. URL: http://www.rspu.edu.ru/university/publish/schools/2/1.html

20. Шедяков В.Е. Межпарадигмальный переход в структуре и организации международной жизни. Research, challenges and development prospects in the area of social sciences / ed. board: J. Kloc, U. Kempińska, Z. Brenda. Wloclawek : Baltija Publishing, 2020. C. 301-325. DOI https://doi.org/10.36059/978-9934-588-42-6/301-325

21. Shedyakov V. Creation and realization of organizational-management strategy during paradigm transformation. Organizational-economic mechanism of management 
innovative development of economic entities / ed. by M. Bezpartochnyi. Przeworsk : WSSG, 2019. Vol. 3. P. 345-364.

22. Шедяков В.Е. Развитие социальной справедливости: место социетального управления. Theoretical and applied researches in the field of pedagogy, psychology and social sciences: Proceed. of Intern. Scient.-Pract. Conf. Kielce, December 28-29, 2016. P. 144-147.

23. Шедяков В.Е. Менеджмент эпохи форсированных социально-экономических трансформаций. Modern Transformation in Economics and Management: Proceed. of III Intern. Scient. Conf. Klaipeda, March 29, 2019. Part II. P. 35-38.

24. Шедяков В.Е. Управление стратегическими трансформациями: возможности и ограничения. Economy without borders: Integration, Innovation, Cross-border cooperation: Proceed. of Intern. Scient. Conf. Kaunas, August 26, 2016. P. 246-248.

25. Шедяков B.Е. Политико-экономическая стратегия форсированных трансформаций. Strategies for Economic Development: The experience of Poland and the prospects of Ukraine / ed. by A. Pawlik, K. Shaposhnykov. Kielce : Baltija Publishing, 2018. Vol. 1. P. 287-303.

26. Шедяков В.Е. Организационно-управленческие ресурсно-методологические возможности обеспечения конкурентоспособности. Theoretical and practical aspects of the development of modern science: the experience of countries of Europe and prospects for Ukraine / scient. ed. \& project dir. A. Jankovska. Part I. Riga : Baltija Publishing, 2018. P. 495-517. DOI dx.doi.org/10.30525/978-9934-571-30-5_25

27. Ackoff R.L. A concept of corporate planning. New York : Wiley-Interscience, 1969. $158 \mathrm{p}$.

28. Шедяков В.Е. Планирование в нестабильной экономике: возможности и границы. Prognostication and planning of economic development: microeconomic and macroeconomic levels / ed. by J. Žukovskis, K. Shaposhnykov. Kaunas : Baltija Publishing, 2019. Vol. 1. P. 240-256.

29. Gamble A. Crisis Without End? The Unravelling of Western Prosperity. Palgrave Macmillan, 2014. 240 p.

30. Бурега В.В. Социально-адекватное управление: концептуализация модели. Донецк : ДонГУУ, 2005. 171 с.

\section{References:}

1. Galbraith J.K. Economics \& the Public Purpose. Boston: Meridian, 1988. 321 p.

2. Medvedev V.A. (2010) Ustoychivoe razvitie obshchestva: modeli, strategiya [Sustainable development of society: models, strategy]. Moscow: Akademiya. (in Russian)

3. Lukinov I.I. Evolyutsiya ekonomicheskikh sistem [Evolution of economic systems]. Moscow: Ekonomika. (in Russian)

4. Shedyakov V.E. (2019) Antikrizisnye mery v kontekste mezhparadigmal'nogo perekhoda [Anti-crisis measures in the context of an inter-paradigm transition]. Proceedings of the III International Scientific Conference Anti-Crisis Management: State, Region, Enterprise (France, Le Mans, November 22, 2019). Le Mans, France: Baltija Publishing, pp. 10-13.

5. Shedyakov V.E. (2016) Transformatsii pri stanovlenii «umnogo obshchestva»: tsikly, upravlyaemost, subektnost [Transformations in the formation of a «smart society»: cycles, controllability, subjectivity]. Proceedings of the International Scientific Conference From the Baltic to the Black Sea Region: the national models of economic systems (Riga, March 25, 2016). Riga: Baltija Publishing, pp. 14-17.

6. Shedyakov V.E. (2016) Ekonomika upravlyaemaya, samoupravlyaemaya i neupravlyaemaya [Economy controlled, self-managed and unmanaged]. Proceedings of the 
International Scientific Conference Integrated business structures: models, processes, technologies (Chisinau, November 25, 2016). Republic of Moldova: Baltija Publishing, pp. 5-7.

7. Shedyakov V.E. (2015) Aktivizatsiya nauchno-intellektual'nogo potentsiala kak resurs strategicheskogo upravleniya [Activation of scientific and intellectual potential as a resource for strategic management]. Kherson: Helvetyka, pp. 148-172. (in Russian)

8. Shedyakov V.E. (2017) Vozmozhnosti i riski epokhi: nauchno-issledovatel'skaya refleksiya - refleksivnoe upravlenie - refleksivnaya modernizatsiya [Opportunities and risks of the era: scientific research reflection - reflexive control - reflexive modernization]. Management of modern socio-economic systems. Kaunas: Baltija Publishing, vol. 1, pp. 201-218.

9. Mechnikov I.I. (1988) Etyudy optimizma [Studies of optimism]. Moscow: Nauka. (in Russian)

10. Shedyakov V.E. (2019) Kul'tura prinyatiya i realizatsii resheniy v giperkonkurentnoy srede [A culture of decision-making and implementation in a hypercompetitive environment]. Proceedings of the II International Scientific Conference Development of Socio-Economic Systems in a Global Competitive Environment (France, Le Mans, May 24, 2019). Le Mans, France: Baltija Publishing, pp. 149-150.

11. Shedyakov V.E. (2019) Sotsial'naya pedagogika i ekonomicheskaya vlast' [Social pedagogy and economic power]. Modern educational space: the transformation of national models in terms of integration: Proceedings of the II International Scientific Conference (Germany, Leipzig, October 25, 2019). Leipzig: Baltija Publishing, pp. 157-159.

12. Shedyakov V.E. (2017) Osushchestvlenie paradigmal'nykh transformatsiy: sorezonirovanie strategii, taktiki i operativnogo iskusstva $\mathrm{V}$ upravlencheskikh kompozitsiyakh [Implementation of paradigmatic transformations: co-resonance of strategy, tactics and operational art in management compositions]. Development and modernization of social sciences: experience of Poland and prospects of Ukraine / Maria Curie-Sklodowska University. Lublin: Baltija Publishing, pp. 282-307.

13. Buzgalin A.V., Kolganov A.I. (2009) Predely kapitala: metodologiya i ontologiya [Capital limits: methodology and ontology]. Moscow: Kul'turnaya revolyutsiya. (in Russian)

14. Castells M. (2010) The Power of Identity. The Information Age: Economy, Society and Culture. Vol. II. NY.: Wiley-Blackwell, 584 p.

15. Trout J., Rivkin S. Differentiate or Die: Survival in Our Era of Killer Competition. New York: Wiley, 272 p.

16. Shedyakov V.E. (2018) Organizatsionno-upravlencheskie podvizhki kak otrazhenie global'nykh transformatsiy [Organizational and managerial shifts as a reflection of global transformations]. Anti-Crisis Management: State, Region, Enterprise: Proceed. of II Intern. Scient. Conf. Le Mans, November 23, 2018. Part I. P. 9-11.

17. Shedyakov V.E. (2019) Vektor postsovetskikh transformatsiy kak faktor global'nykh preobrazovaniy [The vector of post-Soviet transformations as a factor of global transformations]. Economy and Society: the Modern Foundation for Human Development: Proceed. of III Intern. Scient. Conf. Leipzig, April 26, 2019. P. 40-41.

18. Shedyakov V.E. (2020) Ukreplenie sotsiokul'turnogo osnovaniya - uslovie ustoychivogo politiko-ekonomicheskogo razvitiya [Strengthening the socio-cultural foundation is a condition for sustainable political and economic development]. Modern Transformations in Economics and Management: Proceed. of IV Intern. Scient.-Pract. Conf.. Klaipeda, March 27, 2020. P. 85-88.

19. Serikov V.V. Paradigma sovremennogo obrazovaniya: orientatsiya na lichnost'. URL: http://www.rspu.edu.ru/university/publish/schools/2/1.html

20. Шедяков В.Е. Межпарадигмальный переход в структуре и организации международной жизни. Research, challenges and development prospects in the area of social sciences / ed. board: J. Kloc, U. Kempińska, Z. Brenda. Wloclawek: Baltija Publishing, 2020. C. 301-325. DOI https://doi.org/10.36059/978-9934-588-42-6/301-325 
21. Shedyakov V. (2019) Creation and realization of organizational-management strategy during paradigm transformation. Organizational-economic mechanism of management innovative development of economic entities / ed. by M. Bezpartochnyi. Przeworsk: WSSG, vol. 3, pp. 345-364.

22. Shedyakov V.E. (2016) Razvitie sotsial'noy spravedlivosti: mesto sotsietal'nogo upravleniya [The development of social justice: the place of societal control]. Theoretical and applied researches in the field of pedagogy, psychology and social sciences: Proceed. of Intern. Scient.-Pract. Conf. Kielce, December 28-29, 2016. P. 144-147.

23. Shedyakov V.E. (2019) Menedzhment epokhi forsirovannykh sotsial'noekonomicheskikh transformatsiy [Management of the era of forced socio-economic transformations]. Modern Transformation in Economics and Management: Proceed. of III Intern. Scient. Conf. Klaipeda, March 29, 2019. Part II. P. 35-38.

24. Shedyakov V.E. (2016) Upravlenie strategicheskimi transformatsiyami: vozmozhnosti i ogranicheniya [Management of strategic transformations: opportunities and limitations]. Economy without borders: Integration, Innovation, Cross-border cooperation: Proceed. of Intern. Scient. Conf. Kaunas, August 26, 2016. P. 246-248.

25. Shedyakov V.E. (2018) Politiko-ekonomicheskaya strategiya forsirovannykh transformatsiy [Political and economic strategy of forced transformations]. Strategies for Economic Development: The experience of Poland and the prospects of Ukraine / ed. by A. Pawlik, K. Shaposhnykov. Kielce: Baltija Publishing, vol. 1, pp. 287-303.

26. Shedyakov V.E. (2018) Organizatsionno-upravlencheskie resursno-metodologicheskie vozmozhnosti obespecheniya konkurentosposobnosti [Organizational and managerial resource and methodological opportunities to ensure competitiveness]. Theoretical and practical aspects of the development of modern science: the experience of countries of Europe and prospects for Ukraine. Riga: Baltija Publishing, pp. 495-517. DOI: dx.doi.org/10.30525/978-9934-571-30-5_25

27. Ackoff R.L. (1969) A concept of corporate planning. New York: WileyInterscience, $158 \mathrm{p}$.

28. Shedyakov V.E. (2019) Planirovanie v nestabil'noy ekonomike: vozmozhnosti i granitsy [Planning in an unstable economy: possibilities and limits]. Prognostication and planning of economic development: microeconomic and macroeconomic levels. Kaunas: Baltija Publishing, vol. 1, pp. 240-256.

29. Gamble A. (2014) Crisis Without End? The Unravelling of Western Prosperity. Palgrave Macmillan, 240 p.

30. Burega V.V. (2005) Sotsial'no-adekvatnoe upravlenie: kontseptualizatsiya modeli [Socially adequate management: conceptualizing the model]. Donetsk: DonGUU. (in Russian) 